\title{
Landscape and Politics on the Olympic Peninsula: Social Agendas and Contested Practices in Scientific Forestry
}

Alx Dark 1

The United States incorporated the Olympic Peninsula, an isolated portion of Washington State, late in the last century toward the end of an era of territorial expansion (Figure 1). Settlers arrived in the 1890s but the dense rainforests of the region made the familiar pattern of homesteading impossible (R. White 1980:115-116). Instead the region met the country's expanding need for resources through the salmon fishery and coastal logging operations. The timber industry in particular has radically transformed the peninsular landscape in the last hundred years, precipitating an environmental crisis. Despite the beauty of the region's temperate rainforests, and the impressive size of the peninsula's redcedar trees, most of the state and privately held forests on the Olympic Peninsula have been logged and converted to monocultural tree farms. ${ }^{2}$ Conflicts over logging the remaining old-growth forests have been protracted and bitter. Observing these events in recent years, I have been struck by the degree to which land-management science and policy have been reconceived in terms of "holistic" and "ecosystem-oriented" land management, involving "interagency teams" and "partnerships with industry" to achieve "consensus"--at a time of intense conflict, this is certainly an ambitious agenda of social and ecological integration. Why has this agenda come about and what does it tell us about the future of resource management and environmental conflict on the Olympic Peninsula? In this article I argue that scientific land management has historically involved an element of social control. Increasing political conflict over the environment has made this social project more difficult, causing land managers and scientific experts to rethink the underlying social ideals of scientific land management.

1. I would like to thank Karen Blu, Owen Lynch, Sarah Franklin, T.J. Jackson Lears and Lisa McArthur, all of whom read earlier versions of this work and made thoughtful comments toward its improvement. I would also like to thank the anonymous reviewers of the JPE who offered their well-informed criticisms on an earlier draft of this article.

2. Along with areas of New Zealand and Chile, the Pacific Northwest coast of North America is one of three areas in the world harboring sufficient climate and soil conditions for the development of temperate rainforests. These forests were originally composed of western redcedar, western hemlock, Sitka spruce, and Douglas fir, with redcedar trees of the Olympic Peninsula reaching a size comparable in height and girth to the redwood giants of California. Clear-cut logging and the "second growth forests" can cause erosion, destroy soil microorganisms, damage salmon and wildlife habitat, and reduce the biodiversity of an ecosystem. 


\section{FIGURE 1. Washing State and the Olympic Peninsula}

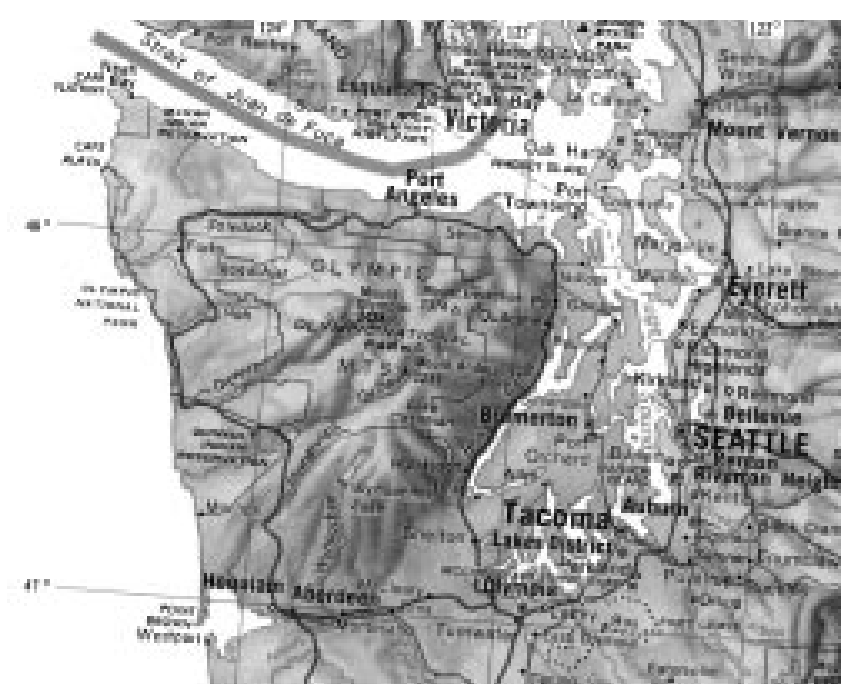

Because the state sponsors most forestry science as a means to regulate resource extraction, I consider the state and science to be related enterprises that have profoundly affected the landscape of the peninsula. Cultural studies scholars have demonstrated the role of science in organizing nature as an object of knowledge and technical manipulation (R. Harrison 1992; C. Merchant 1989); similarly, I will explore the use of science on the peninsula as it is mobilized to eliminate social conflict over environmental management initiatives (often through the "naturalization" of social categories and processes; D. Haraway 1991, 1992; A. Ross 1991; M. Strathern 1992). Despite claims of efficacy in monitoring, improving, and protecting the natural world, scientific management has produced the fragmented forest landscape of the peninsula and reproduced the conditions for future resource extraction in the region. In turn, land managers and technical experts have had to address not only opposing political and social forces, but also the contradictory landscape itself. They have envisioned an ever-widening system of dispersed command and control over civil society and nature, which draws upon an increasingly elaborated, generalized language of systems and exchange (D. Haraway 1991:161-165). This shift in the role of scientific knowledge and state authority, away from the enlightenment ideal of a future guided by a singular exercise of reason over the natural world, to the present cybernetic concern to contain a profusion of complexity and crisis, I term a post enlightenment rationality. This argument has important theoretical consequences, as I argue that land managers see nature as the pragmatic product of social and political conflicts. This runs contrary to the current assertion by cultural construction theorists (such as W. Cronon 1995) that the natural world (e.g. wilderness) is largely represented in essentialistic terms.

I traveled to the peninsula two or three times a year, while attending school as an undergraduate in Seattle. At the same time, the spotted owl conflict occupied the attention of the Pacific Northwest and local communities had been mobilized by "Wise Use" organizations to protest environmental management initiatives. Like other visitors to the region, I first noticed shortcomings of land management through the landscape itself, 
through the contradictory spaces of industrial logging--mills, scaling stations, truck stops, clear-cuts--and the ancient rainforests which have been protected in Olympic National Park. This patchwork of land-use strategies on the Olympic Peninsula has left the forests heavily fragmented and many watersheds badly damaged (F. Swanson et al. 1989), but it has also provided a crucial context for comparing, measuring, and experiencing environmental change.

Corporations, land management agencies, and local people are all aware of the potential interpretation of this landscape and actively modify it (e.g. through signs, stands of trees, road closures and public-education spaces like museums and visitor centers) to guide the interpretation of the peninsula. Previous anthropological studies of political conflict have likened political processes to "social dramas" (cf. V. Turner 1974) in which individuals enact and give substance to the ideals and values which motivate political activities (F. Ginsburg 1989; L. Krasniewicz 1992; A. Pearce 1993). While many of these studies have focused on protests (where the communication of values becomes highly public and assertive), I shift attention here to the entire landscape of the peninsula as a politicized space, expressing the values of scientific management or its opponents. In the case of local Native American and logging communities, these activities challenge and reorder the projects of industry, environmentalism, the state, and science, in an ongoing assertion of cultural difference between social groups that are spatially and economically interdependent (A. Gupta and J. Ferguson 1992:14; M. Henderson 1992). ${ }^{3}$ These differences support collective identity, but they are also the culturally and historically significant context from which social groups make particularistic claims on the peninsula's resources, challenging the project of social control embedded in scientific management ideology.

In this article I draw on an eclectic set of documentary materials and first-hand experience traveling and working on the peninsula. In addition to visiting the area, the peninsula became an important case study for my graduate studies in preparation for fieldwork on environmental politics in logging communities. While traveling to British Columbia in 1995 and 1996, where I conducted doctoral dissertation fieldwork on the social history of logging politics in Clayoquot Sound, I took the opportunity to visit the peninsula and some of the key locations mentioned in this article. In 1996 my wife, Lisa McArthur, worked for the Environmental Protection Agency, reviewing the Forest Service's implementation of the Northwest Forest Plan (NFP) in the southeast of the peninsula. This afforded me an additional opportunity to speak with several state and federal employees about the recent changes in regional land-management policy. In the final section on loggers and their supporters, and Native American communities, I have also depended on my knowledge of communities in Clayoquot Sound, which have experienced similarly high-profile political conflicts over logging temperate rainforests.

In the first of three sections, this article reviews the history of the Olympic Peninsula and the contradictory imperatives of preservation and development that shaped its landscape. Section two discusses the role of forestry, ecology, and management ideology in the social projects of land management agencies such as the U.S. Forest Service and the state of Washington's Department of Natural Resources. In the final section, this article

3. I use the term "logger" loosely here and include other timber workers such as truck drivers and mill workers (see M. Carroll 1994). The phrase "culture of nature" comes from A. Wilson 1992; see e.g. A. Tsing 1993. 
presents some of the ways that local residents of the peninsula have responded to these management projects, through the landscape as well as other public political spheres.

\section{A Geography of Conflict}

On the Olympic Peninsula, periodic waves of capital investment in permanent infrastructure, followed by capital mobility and abandonment of the area, have led to uneven resource extraction and a regional boom and bust economy, within which the people of the peninsula have come to understand the natural world around them (B. Warf 1988). As early as 1900, companies operating in the Great Lakes region exhausted the available supply of timber and relocated to the Pacific Northwest, with San Francisco, South America, and Asia providing ready markets (M.Williams 1989:289). The first Governor of Washington Territory, Isaac Stephens, hastily concluded treaties with Native Americans on the peninsula in 1855 (C. Marino 1990:170), limiting their control over the region to small reservations along the coast. The United States subsequently transferred much of the peninsula into the forest preserve system in 1887 (C. Lien 1991:7-10), although a large portion of the peninsula came under corporate ownership. In addition to railroad land concessions in the southern portion of the region, a common form of fraud at the time involved loggers purchasing homesteading claims, which were then consolidated by mill owners into large timber tracts (C. Lien 1991:27; M. Williams 1989:310).

The large area of public land that remained at the turn of the century was managed under different government agencies, including the US Forest Service, the National Park Service and Washington state's Department of Natural Resources. Initially the Forest Service managed all lands on the peninsula through its "conservation through use" philosophy and orientation toward logging, but eastern environmental groups fought successfully to have a square area at the center of the peninsula set aside as a national monument in 1909 (C. Lien 1991:37-38; B. Twight 1983). Olympic National Monument included the Olympic Mountains and contained forests that logging crews could not access given the technology of the era. When the national monument became a national park in 1938, and environmentalists attempted to extend the national park boundaries to include the old growth forests on the western slope of the peninsula, they met with stiff political opposition from the Forest Service and the timber industry. The Bogachiel, Hoh, Clearwater, Queets and Quinault River valleys, all on the western slope, have been at the center of virtually all subsequent conflicts over the park's boundaries; only the Bogachiel and Queets eventually received extensive protection. Efforts to protect the ocean shoreline and beaches from Kalaloch northwards to the Makah Indian Reservation dragged on until the park boundary was finally extended in 1986 (C. Lien 1991:197-198, 312). ${ }^{4}$

Tourism also began on the peninsula around the turn of the century. Large resorts for relatively wealthy patrons were built along the beach just north of Grays Harbor (P. Capoeman 1990, J. M. Storm, D. Chance, et al.:140-143). The construction of Highway

4. However, even park boundaries have not definitively removed the western river valleys from the possibility of logging. For example, under the guise of removing "insect infested" and "diseased" wood, the Park Service itself licensed substantial logging in the park during the 1940s and 1950s (C. Lien 1991:272). Part of the Bogachiel River valley was also removed from the park in one of countless boundary renegotiations (C. Lien 1991:334). 
101 starting in the 1920 s, and the development of automobile tourism, have opened most of the peninsula to the enjoyment--and the urban gaze--of a growing number of tourists. Automobile tourism, camping, hiking, and backpacking have made it economically feasible and desirable to avoid developing scenic areas such as beaches, rivers, and mountains. Despite a number of development proposals, the area from Grays Harbor north to Moclips is the only area of the western coast to have been substantially developed (C. Lien 1991:300-302; 323-325). Tourism continues to be an important part of the local economy, and as the Seattle metropolitan area grows, it is likely to supply ever-greater numbers of visitors to the peninsula (M. Miller 1987:63).

The contradictory economic forces of logging and tourism, and the political forces of conservation and environmental protection, have produced stark contrasts in land use on the peninsula. Although much of the deforestation is shielded through the use of "beauty strips" of uncut trees along either side of the road, travelers inevitably encounter clear-cut. Timber corporations and the state erect signs along trails and roads to inform travelers that the roadside clear-cuts and sapling groves are "managed forests." On one walk I followed a path away from a highway picnic area, only to find that the forest that once provided a wooded walk had been clear-cut, extending about half a mile from the path. A sign had been erected with a timeline that has become a familiar marker in the landscape of the peninsula:

$\begin{array}{ll}\text { First Harvest } & 1905 \\ \text { Second Harvest } & 1984 \\ \text { Planted } & 1985 \\ \text { To Be Thinned } & 2000 \\ \text { Third Harvest } & 2035\end{array}$

Scientific forestry adopts several terms from agriculture, including "planting," "crop," and "harvest," to frame clear-cut as a step in a process of forest renewal, under the guidance of scientific management. Companies and government agencies place these signs at the borders between different uses of the forest, so that travelers in the area encounter a narrative about these abrupt changes, one that places them in an orderly series of sustainable transformations of the landscape. Just as important, managing agencies assert through these signs that they are themselves stable entities that will be present to see the forest harvested in the next century (history suggests this prediction is uncertain, particularly for companies). In short, these signs attempt to mediate economic and political contradictions in the landscape of the peninsula.

From the Second World War to the 1970s, policymakers attempted to reconcile the proliferating number of land users and their contradictory visions for land management by including the concept of "multiple use" in legislation. The Multiple Use - Sustained Yield Act of 1960 directed federal agencies to manage the national forests for the uses of "recreation, range, timber, watershed, and wildlife and fish purposes" (R. Percival et al. 1996:105). Although the Forest Service was no stranger to the multiple use concept, in practice forest managers remained convinced that logging enhanced all other uses. In one timber management plan drafted in 1965, the Forest Service specified that clear-cuts would "break the monotony of the scenery," improve the possibilities for berry picking, and improve hunting by increasing browse for elk and deer, while logging roads would open up the forests for recreation (D. Clary 1986:172). Although the agency was confident throughout this period in its ability to "educate and inform" the public about the soundness 
of Forest Service management, in the 1960s and 1970s clear-cuts precipitated a battle with environmentalists over the agency's policies.

Intense conflicts over Native American fishing rights (see below) and the logging of old- growth forests on federal lands occupied land managers and the public in the 1970s. By the 1980s, the state of Washington and Native American tribes were looking for another way to address resource conflicts beside litigation. The Timber, Fish, and Wildlife Agreement (TFW), reached in 1987 by twenty-four environmental, native, and timberindustry groups, created a new process for regulating and managing the lands of the state of Washington (C. Halbert and K. Lee 1990; J. Waldo 1988). The TFW is an agreement, not a legally binding management regime. Under the direction of Washington's Department of Natural Resources (DNR), members of the cooperating organizations create assessment teams to discuss logging methods on a site-by-site basis, with the goal of establishing logging plans that will protect other values such as salmon and wildlife habitat, water quality, and native cultural sites (C. Halbert and K. Lee 1990:141-147). As a mediation process, TFW has reduced litigation, but at the cost of setting aside the major issues that generate environmental conflicts in the Pacific Northwest--the cumulative impact of logging and the lack of a landscape-level approach to protecting old-growth forests (C.Halbert and K.Lee 1990:146). The public cannot participate in the assessment process, TFW members raise their own funds to participate (environmental organizations depend solely on grants and volunteers), and property owners voluntarily set aside land to protect nontimber values. The ecological value of these set-aside lands is unknown, because the DNR does not enforce assessment team recommendations or conduct followup studies to determine the consequences of these recommendations when they are implemented (C. Halbert and K. Lee 1990:153,155).

The approach of the DNR and the state of Washington in the TFW process exemplify the recent shift toward a postenlightenment rationality. Abandoning the enforcement of a common good, the state now arbitrates between political interests. As Halbert and Lee, as well as Waldo have noted, the TFW process occurred because "the power of the parties was relatively equal when negotiations began" (C. Halbert and K. Lee 1990:159), as all parties had won litigation over timber-management regimes (J. Waldo 1988). However, the promise of resolving conflict through "mediation" has been such that the TFW concept has been exported to other regions and other disputes, often where there is no parity between the "interested parties" and where "consensus" has become a means to advance the political objectives of one of the parties--as happened shortly after the TFW process when the Clinton administration created the Northwest Forest Plan.

In the late 1980s and early 1990s, logging on the peninsula was thrown into further disarray when the northern spotted owl and several species of salmon were put on the endangered species list (B. Knickerbocker 1991). The spotted owl controversy began in 1986 when the Forest Service established 1.2 million acres of federal forest as spotted owl habitat and announced it would $\log 60$ percent of this land over the next 50 years. When a revised plan still seemed inadequate to protect the owl, environmentalists took the Forest Service to court, arguing the Service was failing to protect the spotted owl as mandated under the Endangered Species Act and other laws. An injunction was granted in October of 1989 on 135 timber sales in spotted owl habitat. Subsequent attempts by the Forest Service to devise a management plan were also taken into the courts and also found inadequate. Although the acreage of land required to protect the owls grew with each report to 11.6 million acres by 1991, appropriations riders were passed by Congress that 
limited the impact of the injunctions on logging activities, and industry lobbied successfully to reduce the proposed protected area to 6.9 million acres.

Nevertheless, after four years of litigation, the Forest Service could not produce a plan to protect the owl that would lift the injunctions against logging on owl habitat. In the midst of what had become a drastic and necessary act of environmental intervention (L. Caldwell et al. 1994), the Clinton administration declared in April of 1993 that the time had arrived for a "compromise." With an acute sense of state theatrics, and in a language of integration and conflict resolution, the administration called a Forest Conference in which all the "interested parties" were brought around a table. Based on the Forest Conference, the administration subsequently issued the Northwest Forest Plan (NFP), which restored logging on federal forests despite the acknowledgment that spotted owl populations would suffer (lands protected from logging were increased to 7.4 million acres with plans to set aside 2.6 million acres of riparian land; J. Proctor 1995:279). At the same time, the NFP has not restored harvesting to previous levels and does not insure the stability of the timber industry. The NFP has pleased neither environmentalists nor local companies, and promises both further economic hardship and conflict in the future (M. Trumbull 1993).

The TFW and NFP share a discourse of mediation and consensus decision-making at a time of reduced public participation and continued resource extraction on the peninsula. Changes in land management discourse from concern about "community stability" toward a more recent discourse of "orderly change," also reflect (sometimes in surprising ways) recent changes in the scientific understanding of forest ecosystems. For example, the temperate rainforest was once seen to be a stable "climax community," but recently ecologists have appreciated that ecological systems can be open-ended processes involving directed changes. This suggests that anthropogenic changes cannot be measured in terms of an unchanging, wilderness condition on the peninsula (D. Demeritt 1994), making anthropogenic change, in a certain sense, more "natural." Although these scientific developments have had complex and debatable political consequences (see e.g. W. Cronon 1995; and the response of M. Soulé and G. Lease 1995, particularly M. Soulé 1995:148159), the Olympic Peninsula demonstrates that scientific knowledge of the forest has changed in ways which renew the usefulness of science in legitimating state management regimes. Current scientific initiatives to unify the knowledge generated by forestry, ecology, sociology, genetics and economics fit smoothly into the project of managing opposition to state and industry policy. This is the very essence of the shift toward a postenlightenment rationality.

\section{Scientific Forestry and Social Management}

The contemporary period has seen the development of a discourse of technocratic management that unifies previously separate discourses in forestry, ecology, state technocratic management, and economics under the paradigm of systems theory. Although, the technocratic impulse in social management certainly has part-origins in the modernism of the 1930s (A. Ross 1991:117-125), the language and mathematics of systems theory was only subsequently developed and adopted. One consequence has been the fusion of "society" and "nature" as a set of interactions, regulatory contests and flows between producers and consumers that are both economical and functional. This model, which attempts to suppress political and social contradictions, I refer to as a postenlightenment rationality (for an example of social theory that grapples with this 
“collapsed" discourse, see D. Haraway 1991:149-181). Environmentalists must increasingly confront the attempt to manage a "compromise" landscape that would effectively exclude ecological preservation or restoration in favor of a "bioeconomic" nature (nature as an appendage of economy in which people are part of utilitarian ecosystems). In this section we examine the social and political dimensions of scientific forestry and ecology.

Forestry in its modern form was the product of eighteenth-century enlightenment philosophy as it was applied to the planning of the emerging state economies of central Europe, which included substantial forest holdings (previously aristocratic game preserves; H. Lowood 1990:318). As it was developed in Germany, forestry involved four central principles: (1) minimizing the diversity of the forest through measured (rectilinear) regularities in cutting and replanting; (2) applying "the balance sheet," or double entry accounting system to describe "the related components of planning and biological growth that concerned the forester in his effort to balance supply and demand;"(3) sustaining a constant level of wood production; and (4) assessing the actual mass or volume of wood in a stand of trees instead of relying on an area-based system of measurement $(\mathrm{H}$. Lowood 1990:333-338). Subsequently, these principles of forest rationalization and management became the model for all modern forestry, including that practiced by the U.S. Forest Service (D. Clary 1986:6).

The U.S. Forest Service and the state of Washington's Department of Natural Resources operate apart from, but responsive, to the political struggles of civil society. Whereas the political will on forestry issues may be mandated by popular vote, its implementation requires scientific knowledge and technical training. Land management agencies provide this knowledge by training and employing a group of professionals who follow the principles of forestry science with little immediate supervision by the executive or legislative branches of government. Agency personnel believe there is a technically rational way to approach forestry and they act on this belief, often in the teeth of competing claims from industry and environmentalists about the best way to manage forested lands.

Certainly clearcutting provides an example of conflict between forestry management and its opponents. Research on the impacts of clearcutting remains decidedly ambivalent and its status as a scientific practice is perhaps the most contested aspect of forestry policy, yet it continues to be the preferred method of harvest, and the most economical. With critics unable to challenge the forestry decisions of the Forest Service on the grounds of technical criteria alone, legislation during the 1970s, including the Renewable Resources Planning Act of 1974 and the National Forest Management Act of 1976, laid out in increasing detail the management requirements of the agency. These laws were drafted to "identify problems rather than solve them; they define procedures rather than goals, providing a complicated course for action" (M. Frome 1981:31). Although these laws provide for increased public comment and review of Forest Service management plans, the drafting of environmental impact statements and both five- and ten-year management plans, problems remain. The entire Forest Service was shut down in 1973 in a legal challenge to its right to fell remaining areas of old growth forest in West Virginia, upon which a long tradition of turkey hunting depended (D. Clary 1986:190-192); and in 1991 all logging on the Olympic Peninsula was stopped until the Service developed a plan for protecting the northern spotted owl (W. Dietrich 1992:257-264).

The effect of legislating environmental concerns through the 1970s and 1980s has been to shift emphasis away from periodic crises in interpreting how the national forests should 
be managed to the inscription of procedures for grievance and contest within the functioning of the Forest Service itself. While crisis is unexpected and uneconomical, opposition that arises through procedural channels, such as public reviews, can be effectively controlled (A. Pearce 1993).

Ultimately, shifts in bureaucratic management led to changes in the landscape, as the Roadless Area Review and Evaluation projects (RARE I and II) demonstrate. The RARE projects were conducted in the 1970s to involve the public in the process of identifying wilderness areas in the national forest system, areas where the Forest Service would not build an infrastructure of roads to support logging operations. The construction of roads into previously roadless areas became a focal point of environmental groups who understood that this infrastructure was the first activity towards redefining a forest as a commercial stand of trees. The inventory process of RARE I and RARE II effectively defined what areas would be considered "wilderness," worthy of preservation, or "forest," to be logged on a sustainable basis. Wilderness thus becomes the outcome of human activity, and the RARE reviews "became intensely controversial for to include or exclude a particular site either kept the proposal alive for future action or eliminated it" (S. Hays 1987:472). Although RARE I and II represented an unprecedented attempt to manage political relationships before land use decisions precipitated a crisis, the process was involved and frustrating. Ironically it was five environmentalists, disillusioned with the results of RARE II, who concluded that a more confrontational environmental movement was needed. Shortly after the RARE II process they founded the organization Earth First!, a group which defined many new aspects of "radical" environmental politics in the 1980s (R. Scarce 1990:58).

Part of the crisis that progressive-era conservation foresters expected to manage was the social results of "cut-out-and-get-out" logging, which led to worker migration, unstable rural communities and the threat of monopoly (D. Clary 1986:22). The Forest Service made an ill-fated foray into social management through the Sustained-Yield Forest Management Act of 1944. Strongly supported by the timber industry, it authorized the reservation of sustained-yield units, consisting either of private and federal or exclusively federal lands, "for the exclusive use of local operators" (D. Clary 1986:126). The Service, for its part, saw the cooperative management units as a means by which to regulate private lands, while promising the community stability that would come from "better utilization of the forest, higher local employment, less overexpansion, and an end to fluctuations in population and payrolls" (D. Clary 1986:129; for an excellent discussion of community stability, see G. Machlis and J. Force 1988). Cooperating with the Simpson Timber Company, the Shelton Cooperative Sustained Yield Unit was established on the peninsula in 1946 near the town of Shelton in the southeast of the peninsula. As one Simpson president described the impact of the Sustained Yield unit on Shelton, "soon our plans became the plans of the entire community" (R. Walls 1996:120), a monopoly not just on timber but on the cultural and ideological life of the community which has been ably described by Robert Walls. Although disbanded in the 1980s, the agreement effectively doubled the timber to which the Simpson Timber Company had exclusive access (R. Hoover 1978:92,100), while the Forest Service was able to interpret the agreement to mean they were not under obligation to review the 111,000 acres of federal land in the unit for wilderness status during RARE I and II (C. Lien 1991:357). Although sustained yield units have since been discredited, sorties by land-management agencies into social control continue (J. Drielsma and J. Miller 1990) and they continue to require the means to link biological concepts, such as sustained yield, to social problems such as 
community stability. Ecology has provided a holistic, systematic entrance into this form of knowledge and its concomitant bioeconomic management.

The natural science of ecology was initially conceived through extensive metaphorical references to society, and it continues to be a crucial location for the cultural configuration of "the social" and "the natural" today. Geographers pioneered the study of ecology as the "science of communities" of flora and fauna, after noting that predictable collections of flora and fauna could be expected under certain physical conditions. In the 1930s, ecology shifted from biological metaphors (such as the organism) to a physicochemical model of interaction that relied upon economic terminology and the growth of systems mathematics (D.Worster 1977:302-303). Hoping to eliminate "anthropomorphism" from their science, ecologists dropped the word "community" for the new term of "ecosystem," but in fact ecology came to describe the world in terms of "production" and "consumption." In such a functionalist model of nature-as-system, conflict and contradiction had little place, whereas cooperation came to be "defined, and absorbed, by the functions of production and consumption" as the sole means for comprehending "social integration" (D. Worster 1977:293). In ecology, "integrated circuitry, geochemical cycling," and "energy transfer" mimic the modern economy while nature "becomes a corporate state, a chain of factories, an assembly line" (D. Worster 1977:313). Where ecologists would have originally seen the temperate rainforest of the peninsula as a "climax community," a set of flora and fauna best adapted to the physical conditions of the region and selected through a Darwinian struggle for survival (D. Worster 1977:207), the modern science of ecology concerns itself primarily with the interaction of the rainforest's biological parts. At the same time, the ecological sciences have reproduced a long-standing epistemological confusion between the forest as a set of biological relationships and the forest as a kind of economy.

Whereas ecology has in a sense "socialized" the natural world by relating it to economics, by considering social activity in purely functional and systemic terms, such sciences can quite readily "naturalize" society by reducing it to the level of physical processes. Thus the pollution of Lake Washington near Seattle provides a ready example of an aquatic ecosystem being perturbed by an influx of nutrients (R. Smith 1980:19), while an article on the landscape ecology of the Pacific Northwest considers the impact of clearcutting alongside such natural forces as volcanic eruptions, fires, and watershed dynamics (F. Swanson et al. 1989:196). In a more troublesome example, a report sponsored by the National Research Council (NRC) on the future of forestry research suggests the need for a "sociology of forests." This sociology would consist of studying "the interaction of human social systems and resource management" (J. Gordon et al. 1990), where the goal would be to generate "the knowledge of process and change in sociobiological systems [i.e., timber communities and their livelihood] which is critical to understanding the persistence and change of these rural institutions and ultimately the cultural fabric of community" (J. Gordon et al. 1990:39). Such a "sociology" would apparently drop further attempts at "community stability" in order to govern processes of "sociobiological" change.

Forestry management originally limited the impact of deforestation through time by limiting the size of clear-cuts and spreading them through space, a practice that has resulted in a fragmentation of the forest that threatens ecosystemic functioning. The answer to this problem has come in the form of the "New Forestry" and landscape ecology. "New Forestry" advocates suggest that clear-cuts can be modified to achieve more complex landscapes than clearcutting has created in the past (these modified clearcuts, however, are different from selective logging methods). Through a number of 
methods (planting trees farther apart, leaving trees and debris after a cut, and replanting different ages and species of trees), the characteristics of these clear-cuts would be made to resemble those of old growth forests (W. Dietrich 1992:109). New Forestry would create a compromise landscape where logging continues with mitigated ecological impacts, if these alterations prove effective. At the same time, this new level of biological ambiguity in the landscape erodes distinctions between "wilderness" and "tree farms" and it can provide a justification for continuing to log in old growth forests. Just as state bureaucracies have incorporated political conflicts in order to assure the smooth reproduction of their procedures, New Forestry, landscape ecology, and other ecosystem approaches to land management ultimately promise to manage the forests as a kind of bioeconomy that will integrate, but not resolve, the conflicting ecological and social landscapes of the peninsula.

\section{Discourses of Preservation and Survival}

Native Americans and logging communities on the Olympic Peninsula interrelate issues of class, culture and forestry in ways quite different from the systemic imagination of scientists and bureaucrats. The spatial and cultural productions of the peninsula's communities do not intend to weave the fragmented peninsula together into a unitary project, but instead insist on cleavages that ally classes, cultural groups, and occupations with the natural world, in ways that are contested and political. These claims involve particular assertions of cultural identity and history, and claims about the environment and our ethical relationship to the natural world (e.g. J. Proctor 1995). These assertions of a unique relationship between people and forests make the postenlightenment goal of mediating conflict an act of political intervention, one that seeks to mute social contradictions and often supports existing political relationships in order to pursue an orderly and functional society.

Native Americans of the peninsula live for the most part in a number of small and isolated reservations along the coasts. Located at the ends of roads that lead off from highway 101 like spokes from the hub of a wheel, the Chehalis, Quinault, Hoh, Quileute, Ozette, Makah, Lower Elwa, Jamestown Klallam, and Skokomish Reservations have been marginal spaces since they were established to remove the peninsula's Native American population from settler activity in the region. In 1887, as the forests of the peninsula were transferred into reserves, the Dawes Act authorized the allotment of reservations to individuals, and many reservations (including the large Quinault Reservation) were divided up into square parcels. Subsequently many plots were purchased by timber operators and logged (P. Capoeman, J. M. Storm, D. Chance, et al. 1990). Part of the continuing cultural survival of Native Americans in the area depends on confronting this invisibility and economic marginalization.

Native American communities on the peninsula have had to defend their reserved lands against a number of encroachments by the state, tourists, corporations, and environmentalists. The Quinault Indian Nation, in order to protect its beach from the destructive activities of tourists, closed the beach front road within the borders of the Quinault Reservation to unauthorized traffic (P. Capoeman, J. M. Storm, D. Chance, et al. 1990:204). More importantly, the Quinault tribal council has wrestled the management of timber contracts away from the Bureau of Indian Affairs, which largely squandered reservation timber resources. Only in the last 20 years have the Quinault been allowed to manage their forestry and fishery resources for their own benefit. The Makah tribe, which 
holds a legitimate historical claim upon the Ozette Reservation to the south of the Makah Reservation, had to struggle with environmentalists during the 1960s and 1970s over whether the reserve would be used by the tribe, or whether it would be included in the surrounding National Park in order to create a "pristine" and protected coastline (C. Lien 1991:313-320). The reservations of the peninsula are rural, but include industrial-looking port facilities for the fishing industry that lie next to undeveloped, coastal recreation areas. Presumably environmentalists are worried about the environmental impact that attends such facilities, although these ports are quite small compared to Aberdeen, Port Angeles or Port Townsend. The Makah gained control of Ozette only after agreeing to maintain its wild and scenic values, a laudable promise but an encroachment on the sovereign control of the tribe over its land (C. Lien 1991:318-319). No battle was more fierce, however, than the assertion by all the tribes of the region for their right, secured to them by treaty, to participate in the Pacific Northwest salmon fishery.

Although all the treaties of the area stated that Native Americans would secure their right to fish "in common" with settlers, since the inception of the commercial fishery in 1885 native fishermen have been slowly forced out of the industry either as workers or as owners of fishing vessels through racism and Washington state law (D. Boxberger 1989; D. Parman 1983). By the 1950s, Native Americans began challenging this exclusion through illegal "fish-ins" in defiance of state laws prohibiting the traditional fishery, and through the federal court system (F. Cohen 1986:67-82). In an industry dependent upon an already beleaguered resource (the salmon), the economic consequences of redistributing the salmon catch to treaty fishermen were substantial, and the plaintiff tribes were vehemently resisted by sport and commercial nontreaty fishermen, the state of Washington, and the fish- processing industry. Although a number of cases made it to the Supreme Court and were often decided in favor of Native Americans, native fishermen who fished in protest of state regulations (but in accordance with federal law) were prosecuted and even beaten and shot at by game wardens, police, and white vigilantes (F.Cohen 1986:69; W.Taylor and W.Hanson 1970:107). Finally, in the case U.S. vs. Washington (1973), it was determined that Native Americans indeed had a right to 50 percent of the annual commercial catch of salmon, including steelhead trout, which had been declared a sport fish by the Washington Department of Fisheries (F. Cohen 1986:7). When that case was confirmed by the Supreme Court in 1979, the state of Washington began looking for another way to protect the salmon resource besides litigation against the treaty fishery, leading to the development of "cooperative management" between the tribes and Washington in the 1980s (P. Capoeman J. M. Storm, D. Chance, et al. 1990:218-220; 255-274; J. Waldo 1988). Beginning in 1984, meetings between the state and the treaty fishery tribes laid the foundation for mediating resource conflicts, and led directly to the negotiation of the Timber, Fish, and Wildlife Agreement later in the decade (P. Capoeman 1990:255-270).

Today Native American leaders must balance claims of cultural identity with a demonstration of technocratic expertise in land management. Maintaining this balance can be difficult because whites often interpret Native American business and natural resource management expertise as evidence that native communities are becoming more like their rural neighbors (i.e. assimilating). Paradoxically, as Native Americans demonstrate the ability to participate in natural resource management regimes, they also engage in government and business activities that some whites use to argue that Native Americans are losing their cultural difference--the very difference that legitimates the exercise of treaty rights. Tribal councils are seen as bureaucracies, and bureaucracies are considered 
to be institutions without culturally specific features (discourse that undermines Native American cultural identity in the anti-treaty movement can be seen in C.H. Williams and W. Neubrech 1976).

In addition, conflict over the Ozette Reservation demonstrates that environmentalists will also oppose Native American communities that undertake natural resource extraction industries, even when tribal communities are in need of economic development. Native Americans must thus address multiple audiences and negotiate the unique status of their own land-management activities, which involve both resource extraction and protection. At stake is the political control Native Americans maintain over their lands. Although pressing economic need makes natural resource extraction industries necessary, Native American governments cannot sell their lands and move elsewhere like multinational corporations (nor do they desire to), so the ability to sustain the local fisheries and forests are vital concerns.

In one of many examples from a book sponsored by the Quinault Tribal Council, the author points out that the redcedar forest is important to native people because "it is a reminder of what their ancestors knew" (P. Capoeman 1990 J. M. Storm, D. Chance, et al.:26), and ecological sentiments are themselves "based firmly on aboriginal beliefs" (P. Capoeman J. M. Storm, D. Chance, et al. 1990:206). At the same time, logging is not to be understood as a violent intrusion on the landscape, but a human relationship with the forest that has antecedents in the "ancient art" of falling trees stretching back into aboriginal history.

\begin{abstract}
Even today, the faller's initial inspection of each tree in the stand to be felled is similar to the ancient's approach to a chosen tree. Today's faller touches his tree, pats at it. These are primeval gestures with hardly a thought behind them except the faller's knowledge that he is dealing with a living plant. In their own way, these touches are asking permission to down it, exactly as did the Quinault of old. [P. Capoeman J. M. Storm, D. Chance, et al.1990:146]
\end{abstract}

In comparing a modern faller to his forbearers, the author addresses a common perception that a technological innovation, such as a chainsaw, indicates Native American cultural assimilation. Instead, the author argues, a modern faller's activities continue to involve an unconscious perpetuation of rituals that traditionally accompanied logging by Northwest Coast native peoples (in my research on the Nuu-chah-nulth peoples, I found a number of contemporary references to such ritual activities, including $H$. Nathan 1993:141; D. Neel 1992:59-61,70-71; P. Webster 1978:29). The Quinault thus publicly attempt to assert their right to log the Quinault Reservation in a manner that cannot be dismissed by environmentalists as "business as usual," or by industry as "unrealistic" preservationism. This use of contemporary discourses and practices to highlight continuities in cultural tradition can be seen in another article--coauthored by a Skokomish spiritual leader--that integrates environmental discourse with a Skokomish spiritual explanation of our current environmental crisis (D. M. Pavel and G. B. Miller et al 1993:75).

Timber workers have also had little chance to express their point of view on the recent debates of the peninsula. Often finding themselves spoken for by the timber industry, most environmentalists seem in turn to equate the interests of labor with industry. Responding to recent debates, workers in the mills and forests have used the tourism to the peninsula and their own control over certain kinds of space to communicate their views to an urban audience. This was evident during trips I made to the peninsula in 1990 and 1991, when 
virtually every residence and locally owned business in the town of Aberdeen sported a green sign that read "This Business (This Family) Supported by Timber Dollars." It was not unusual to see bumperstickers in the area that read "Save a Logger, Kill an Owl" or to read T-shirts that said "Loggers are an Endangered Species Too." In Clayoquot Sound where I conducted field research in 1995 and 1996 similar signs appeared which read "This Town for Sale." In British Columbia, the signs had been put up under the organization and encouragement of the local "Wise Use" organization (a movement to counter environmental initiatives that would limit resource industries like logging). In speaking with loggers in that region, the frustrations they expressed toward environmentalists accorded with published accounts on the issue, and they appear to reflect the motivations behind the signs and T-shirts on the Olympic Peninsula (B. Brown 1995; M. Carroll 1994; C. Dumont 1991; T. Dunk 1994; R. Walls 1987; K. Warren 1992). First and foremost, many loggers claim that the high-level decisions of environmental managers have "endangered" a unique "way of life." Loggers and their supporters insist that the urban people who control the political and economic situation of rural communities lack the common sense and firsthand knowledge of the forests to truly understand what has to change in the logging industry. Loggers argue that they live in the country and work in logging because they love to spend time in the forest, and that staying in a rural town presents many hardships they and their families have overcome in order to keep working outdoors. They argue that they themselves are the "true" environmentalists, in contrast to the misguided interference of urban preservationists.

During the 1970s, foreign markets created a boom economy for logging, and small towns like Forks, located on the western slope of the peninsula, grew with the industry. Many of the old growth forests remaining on private land were clear-cut at this time (W. Dietrich 1992:95). At the end of the decade and into the early 1980s, a severe recession and the modernization of mills eliminated many jobs in the area. Larger corporations began investing in other timber producing regions, particularly in the southern United States. Timber companies also used contract laborers, closed union shops, and even in one case opened a mill in Mexico in order to force wage concessions on unionized labor between 1984 and 1986 (A. Brunelle 1990:108-109; J. Miller 1988). Conflicts over environmental protection at the end of the 1980s and 1990s came after a decade of assaults on working people in the region.

Some academics have responded to the economic plight of loggers and argued that their occupation does indeed give them a separate culture of common values and a meaningful relationship to the land that is worthy of "preservation" instead of "extinction" (for other examples of occupational identities as cultures under assault from environmentalism, see N. Einarsson 1993; J. Jorgensen 1984). Certainly loggers, and other workers in the wood products industry, do share certain values:

... logging is clearly more than simply a means of earning wages; it represents a way of life complete with a set of highly developed traditions and shared values that have been cultivated and passed down through multiple generations. The boundary between loggers and nonloggers is very clear to members and they attribute considerable significance to group membership. [They also share...] a strong sense of shared mission and an almost militant esprit de corps... [M. Carroll and R. Lee 1990:45]

According to these authors (who are speaking about falling and yarding crews who actually work in the forests), loggers are independent, take pride in their occupation and in 
the dangers they face (M. Carroll and R. Lee 1990:147). These sentiments are often summarized in the phrase "you can't tell a logger what to do" and the animosity loggers express for the oversight of the Forest Service (M. Carroll and R. Lee 1990:147). Independence is also manifested in the desire to be an independent or "gyppo" contractor, a practice that undermines the power of unions in the logging industry, but allows greater control over the work situation and "allows the worker to claim that he really works for no one but himself and that whatever economic prosperity he and his family enjoy is attributable directly to his individual efforts" (M. Carroll and R. Lee 1990:148). Loggers further assert this independence by changing jobs frequently, and through a "do what it takes to get the job done" work ethic that relies upon a wide knowledge of mechanical repair and flexible problem-solving. Loggers, one way or another, must "get the logs to town."

This occupational identity is partly the basis for the social identity of families and rural communities involved in the timber industry. This can be seen in the music of the 1960s logger and singer-songwriter, Buzz Martin, whose songs romanticized the logging life. His first album, titled "Where There Walks a Logger, There Walks a Man" (R. Walls 1987:33) has subsequently found some currency as an epitaph on gravestones in the Pacific Northwest, along with the depiction of various material elements of the work such as hard hats, caulked boots and the family logging truck (R. Myer 1992). Speaking about their family logging business and environmental politics, one woman notes:

It's disturbing because when I say we are part of the timber industry, we are suddenly The Weyerhaeusers, The Plum Creeks that are making all this money or destroying the land. We are just a small company. We don't make much money and we work very hard; we do this because we love it. [ in K. Warren 1992:18]

On the Olympic Peninsula, the annual "Timberfest" is the local equivalent of the county fair or rodeo, features a number of "timber-related" events, and is just as popular, commercialized, and uncontrived as its other rural counterparts. Like the signs, ribbons and other public symbols mentioned above, these activities and objects assert logging as a central aspect of the identity of rural communities on the peninsula.

The Forks Timber Museum tells the history of timber in the region and reaffirms the occupational identity of logging, but the Forks Logger's Memorial, erected in 1992 next to the museum, tells the story a little more forcefully. Under an A-frame shelter that faces Highway 101, a carving of a logger, standing around ten feet tall, rests his ax on the ground and fixes his gaze over the visitor towards the distant horizon of tall timber. At his feet, a plaque (not unlike a gravestone itself) reads:

In honor of those who first entered the virgin forests and the new mills of the western United States to forge the heritage of the forest products industry.

In tribute to those who perished there in providing the materials for the backbone of America's greatness, her homes, her offices, and her factories.

In gratitude to those working there now.

The forging of an industry "heritage" indicates something more than an industrial history. It is the way of life shared by loggers that has ultimately (so the story of progress goes) meant prosperity for America.

The Memorial demonstrates the uneasy alliance of corporate and worker discourses about logging. Whereas both the communities and the businesses of the Olympic 
Peninsula who donated the Memorial valorize the logging life and its dangers, the Memorial euphemizes and minimizes the danger of logging. The plaque refers to workers who "perish" in the forest, instead of being killed by falling trees, road accidents or mill equipment after a instant's lapsed attention. The names of deceased loggers listed on either side of the monumental lumberjack tell another part of the story of progress. Of the 137 occupational deaths listed in this century, half occurred since the beginning of Forks' timber boom in 1970. At the same time, these 137 deaths must be only a small fraction of timber industry fatalities on the peninsula. Citing statistics for the entire state of Washington, Prouty reports that there were 6,808 fatalities in the mills and forests between 1912 and 1981 (a time period similar to the plaque), and 329 deaths since 1970 alone (A. Prouty 1985:186-187; there is no indication as to how those listed at the memorial were chosen). Apparently, concern for the rationalization of the timber industry and "sociobiological change" has had little effect on occupational safety. Loggers (particularly fallers) are quite aware of the dangers of their industry. Loggers expect they have a one-inthree chance of being killed or seriously injured during the course of their careers (W. Dietrich 1992:32).

Despite a strong occupational and social identity, logging is only one of a number of rural resource-extraction industries in which independence, know-how, republican virtues, rugged machismo, and a dislike for cities are expressed (fishermen provide one other example). Although Carroll and Lee write that changing jobs is "a time-honored custom among loggers in the study area and is apparently a tradition passed down from the very early days of western logging" (M. Carroll and R. Lee 1990:149), in fact frequent change in jobs is a characteristic part of seasonal, rural economies (e.g. R. Judd 1988:181-182). Much of the logger identity, it might just as well be argued, is grounded in rural social organization and economic life.

Academic discussions of logging as a cultural tradition play a role in the cultural politics that situates the political claims of Native American and rural white communities. In this cultural politics, culture has increasingly been interpreted as a means for mobilizing ethnic and racial groups "for the defense of their social and political-economic interests" (T. Turner 1993:423). This idea of cultural mobilization has also been adopted by Wise Use groups, which bring corporate leaders, company managers and labor together through claims of cultural identification to create a reactionary movement against environmental protection initiatives. At the same time, the recent political climate of state and corporate attacks against labor unions has meant a relative absence of class-based critiques of logging and environmental issues (see J. Foster 1993). This has led rural labor towards adopting the language of environmentalism (endangerment and survival) and a conservatively interpreted identity politics (heritage). At the least, I suggest that academic discussions of logging as cultural tradition contribute to this shift from economic and class critiques of timber industry changes, toward an understanding of logging as a struggle of competing cultural claims between environmentalists and loggers.

When academics argue that a rural way of life or occupational culture has been threatened by environmental initiatives, they situate loggers alongside Native Americans, who also pursue land management issues as a matter of cultural survival. The argument that logging sustains a cultural heritage on the peninsula establishes a white cultural claim to the peninsula's resources that competes directly with the interests of Native American communities. However, the relationship of Native American communities to the peninsula is different from that of logging towns like Forks or Aberdeen, and the two should be compared carefully. Native American peoples have a historical relationship to a specific 
place which has been substantiated and sustained (in many but not all cases) by the reservation system. Maintaining a sense of collective culture and identity without a shared land base has proven to be enormously difficult for Native American peoples (Tollefson has chronicled the difficulties of the landless tribes of Puget Sound in this regard; see K. Tollefson 1992a, 1992b).

Although loggers are also part of particular rural communities, those communities depend on forests, not on a particular valley, or coast, or place. I can also adduce examples from my fieldwork in British Columbia of loggers who traveled widely to continue working at their profession, rather than abandoning logging to take another job closer to home (contrary to M. Carroll 1994:118-119). Similarly, the Wise Use movement has championed the rights of private property including the right to "liquidate" forest resources and sell land as property. Changes in the logging industry, which can mean relocating to urban places and taking up new employment, represent a serious hardship for loggers and their families that should not be ignored. I am, however, suspicious of a generalized language of identity politics that implies these changes are a cultural assault on a par with forced assimilation policies and the alienation of reservation lands.

As James Proctor (1995) has argued in the case of conflicting ethical understandings of the forest, these claims cannot be reduced to a common denominator, an underlying social logic which will resolve contradictory histories or contradictory understandings of the natural world. Contradiction and conflict must form a part of our understanding of the Olympic Peninsula and the politics that guide its future.

\section{Conclusions}

The boom and bust resource economy, tourism, environmentalism, and the vision of state scientific land managers have each played a role in the transformation of the peninsular landscape. Contradictory "all-or-nothing" spaces of industrial forestry and old growth forests contributed to the conditions in which environmentalists could assess environmental changes on the peninsula. Environmental conflict over these changes led to several significant periods of development in land management policy and process during the twentieth century. Forestry, which began during the Progressive Era, initially concerned itself with a grand project of "community stability" in timber dependent communities. This period concluded with the acknowledgment of conflicting uses in the Multiple Use-Sustained Yield Act of 1960. Conflict over clearcutting in the 1960s and 1970 s led to a period of legislation that established processes for increased public participation, as part of an effort to identify and address conflicts before natural resource use occurred. Laws such as the Renewable Resource Planning Act and the National Forest Management Act culminated in management processes such as RARE I and II. More recently the strategy for managing conflict has changed again, along with a retreat from "community stability" and a new goal of "orderly change." In essence, the Timber, Fish, and Wildlife Agreement and Northwest Forest Plan have reduced public participation and selected a set of representative organizations and institutions as "interests" who negotiate a "consensus" on future forest use. This model of "interests" coming together around a "table" makes no reference to the power inequalities between the participants.

In forestry science, the vision of an orderly agricultural enterprise gave way in midcentury to the management of ecosystem exchanges and the bioeconomic model of socialnatural management. More recently, however, both ecological science and its implementation have shown a new intellectual flexibility regarding open-ended changes in 
natural systems, a counterpart to the Forest Service's attention to "orderly change" in the social world. The result has been the promotion of an ambiguous landscape of modified clearcutting and wildlife corridors alongside continued clearcutting in old growth forests. Will this approach to resolving land-use contradictions lead to better environmental protection? I am concerned that we are cutting in old growth forests today on the promise of a management plan which can be changed tomorrow, after the old growth has been logged. New areas to be restored, as wildlife corridors for example, may not survive future political battles for the timber resources of the peninsula.

The sciences we have reviewed here often ignore the complexity of society by equating it with natural phenomenon and then proceeding as if, in characterizing human agency in terms of physical explanations, they had exhausted the possibilities of analysis. The social role of these sciences, as we have seen in the case of forest management, partly involves the justification of management itself, even as the failures of past management schemes are becoming apparent in the landscape. One result is a politically drained language of "the interaction of human social systems and resource management" and a compromise landscape that threatens to erase visual distinctions between old growth forests and human-engineered landscapes. This erasure of contradiction in the landscape complements scientific discourse and further obscures the divided interests that exist in logging conflicts.

The peninsular landscape provides a public sphere where contesting notions of the forests and the social responsibilities of government and industry have been enacted by local logging and Native American communities. In addition to more clearly political activities, local residents have used signs on their homes, cars or T-shirts, and any available public place such as museums, galleries, gift shops or even the wall of a bar or restaurant, to express their claims on the peninsula's future. These claims cannot always be reconciled, and past conflicts, such as treaty fishing rights, have only been resolved through the state imposition of a legal mandate. Without the enforcement of treaty fishing rights through the federal courts, later discussions of natural resource dispute "mediation" would have had little meaning or success.

In a certain fashion, recent environmental studies have also subsumed these political conflicts, through the relativist critique of cultural construction theory (a landmark volume in this regard is W. Cronon 1995). Although it acknowledges the validity of different viewpoints on an issue such as logging, cultural construction theory does not avoid the tendency of academic analysis to undermine particularistic historical and ethical claims by relativizing these claims as politically situated cultural discourses. Cultural construction theory has been criticized by environmental activists (e.g. J. Time 1997:22) and academics (e.g. M. Soulé and G. Lease 1995), in part because it offers this "totalizing" gesture which challenges environmental arguments, and in part because it must undermine the intellectual basis (wilderness) for some of the strongest existing environmental protection measures. ${ }^{5}$ Contrary to William Cronon (1995), who argues that a constructivist view of nature would be a corrective to contemporary environmental politics, I argue that constructivist ideas about wilderness now lie at the center of postenlightenment rationality, as evidenced through modified clear-cut, wildlife corridors and concerns about reconstructing natural landscapes and ecosystems (e.g. A. Baldwin and J. de Luce 1994). Whether these concerns legitimate the logging of our remaining old growth forests or form the basis for a stronger environmentalism may be difficult to predict, but the TFW Agreement and the NFP provide reason for caution. It remains a matter of practical political debate and action. 
Two critical convergences have set the stage for the next era of environmental politics. First, the conflicting agendas of use and preservation have both been enacted in the landscape of the peninsula, which has reached a limit in its ability to be transformed through human activity. This has created a fragmented and contradictory space which raises concerns about reconstructing natural landscapes and ecosystems (the NFP acknowledges the need for reconstruction through the establishment of connecting lands between old growth forests). Second, in the convergence of social and natural management, enabled by systems theory, ecology, and other bioeconomic models, the need to assess the social justice of environmental policies becomes particularly acute. Scientific models, with their implicit (and utopian) promise to comprehend social life in order to control political conflict, have increasingly been offered as a substitute for analyses which would examine the dynamics of capitalism, class and race (e.g. J. Bari 1994; B. Brown 1995). Both environmental organizations and state land managers have supported this shift as a means of avoiding attempts to articulate colonial, economic and environmental forms of domination. Current approaches to "consensus" are far from addressing these political inequalities. Until they are addressed, the landscape of protest on the peninsula will remain and will evolve to challenge the coming era of forest use integration.

\section{Bibliography}

Baldwin, A. Dwight Jr. and Judith de Luce (editors)

1994. Beyond Preservation: Restoring and Inventing Landscapes. Minneapolis: University of Minnesota Press.

Bari, Judi

1994. Timber Wars. Monroe: Common Courage Press.

Boxberger, Daniel L.

1989. To Fish in Common: The Ethnohistory of Lummi Indian Salmon Fishing. Lincoln: University of Nebraska Press.

Brown, Beverly A.

1995. In Timber Country: Working People's Stories of Environmental Conflict and Urban Flight. Philadelphia: Temple University Press.

Brunelle, Andy

1990. The Changing Structure of the Forest Industry in the Pacific Northwest. In Community and Forestry. Robert G. Lee and Donald R. Field et al. editors. Boulder: Westview Press.

5. Cronon writes that the political project of the cultural criticism in Uncommon Ground is to create "greater understanding and self-knowledge" among environmentalists, "qualities which, far from weakening environmentalism, should only strengthen and deepen the insights it has to offer" (W. Cronon 1995:20). Although I share Cronon's academic ideals, there is absolutely no a priori reason to believe that cultural criticism will lead to a stronger environmental movement. 
Caldwell, Lynton K., Charles F. Wilkinson and Margaret A. Shannon 1994. Making Ecosystem Policy: Three Decades of Change. Journal of Forestry 92(4): 7-10.

Capoeman, Pauline K., Jacqueline M. Strom, David Chance, et al. 1990. Land of the Quinault. Taholah: Quinault Indian Nation.

Carroll, Matthew S.

1994. Community and the Northwestern Logger: Continuities and Change in the Era of the Spotted Owl. Boulder: Westview Press.

Carroll, Matthew S. and Robert G. Lee

1990. Occupational Community and Identity among Pacific Northwestern Loggers: Implications for Adapting to Economic Changes. In Community and Forestry. Robert G. Lee and Donald R. Field et al. editors Boulder: Westview Press.

Clary, David A. 1986. Timber and the Forest Service. Lawrence: University Press of Kansas.

Cohen, Fay G. 1986. Treaties on Trial: The Continuing Controversy over Northwest Indian Fishing Rights. Seattle: University of Washington Press.

Cronon, William, (editor) 1995. Uncommon Ground: Toward Reinventing Nature. New York: W.W. Norton.

Demeritt, David 1994. Ecology, Objectivity and Critique in Writings on Nature and Human Societies. Journal of Historical Geography 20(1): 22-37.

Dietrich, William 1992. The Final Forest: The Battle for the Last Great Trees of the Pacific Northwest. New York: Penguin.

Drielsma, Johannes H. and Joseph A. Miller 1990. Sustained Yield and Community Stability in American Forestry. In Community and Forestry. Robert G. Lee and Donald R. Field, editors. Boulder: Westview Press.

Dumont, Clayton W. Jr. 1991. Loggers and Radical Environmentalists: Cultural Struggles in Timber Country. Ph.D. Dissertation, University of Oregon.

Dunk, Thomas W. 1994. Talking about Trees: Environment and Society in Forest Workers' Culture. Canadian Review of Sociology and Anthropology 31: 13-34.

Einarsson, Niels 1993. All Animals are Equal but some are Cetaceans: Conservation and Culture Conflict. In Environmentalism: The View from Anthropology. Kay Milton, editor. New York: Routledge.

Foster, John B. 1993. The Limits of Environmentalism Without Class: Lessons From the Ancient Forest Struggle in the Pacific Northwest. Capitalism, Nature, Socialism 4(1): 11-41.

Frome, Michael 1981. The Forest Service, 2nd edition. Boulder: Westview Press.

Ginsburg, Faye D.

1989. Contested Lives: The Abortion Debate in an American Community. Berkeley: University of California Press. 
Gordon, John C., William A. Atkinson, Ellis B. Cowling et al. 1990. Forestry Research: A Mandate for Change. Committee on Forestry Research, National Research Council. Washington: National Academy Press.

Gupta, Akhil and James Ferguson 1992. Beyond "Culture": Space, Identity and the Politics of Difference. Cultural Anthropology 7(1): 6-23.

Halbert, Cindy L. and Kai N. Lee 1990. The Timber, Fish, and Wildlife Agreement: Implementing Alternative Dispute Resolution in Washington State. The Northwest Environmental Journal 6: 139-175.

Haraway, Donna

1991. Simians, Cyborgs and Women: The Reinvention of Nature. New York: Routledge

1992. The Promises of Monsters: A Regenerative Politics for Inappropriated Others. In Cultural Studies. Lawrence Grossberg, Cary Nelson and Paula Treichler, editors. New York: Routledge.

Harrison, Robert Pogue 1992. Forests: The Shadow of Civilization. Chicago: University of Chicago Press.

Hays, Samuel P. 1987. Beauty, Health, and Permanence: Environmental Politics in the United States, 1955-1985. New York: Cambridge University Press.

Henderson, Martha L.

1992. American Indian Reservations: Controlling Separate Space, Creating Separate Environments. In The American Environment: Interpretations of Past Geographies. Lary M. Dilsaver and Craig E. Colten, editors. Lanham: Rowman and Littlefield.

Hoover, Roy O.

1978. Public Law 273 Comes to Shelton: Implementing the Sustained-Yield Forest Management Act of 1944. Journal of Forest History 22(2): 86-101.

Jorgensen, Joseph G.

1984. Land is Cultural, So is a Commodity: The Locus of Difference among Indians, Cowboys, Sod-Busters and Environmentalists. The Journal of Ethnic Studies 12(3): $1-21$.

Judd, Richard W.

1988. Reshaping Maine's Landscape: Rural Culture, Tourism, and Conservation, 1890-1929. Journal of Forest History 32(4): 180-190.

Knickerbocker, Brad

1991. Sockeye Salmon Listing Will Impact Whole Pacific Northwest Economy. Christian Science Monitor, 19 November: 7.

Krasniewicz, Louise

1992. Nuclear Summer: The Clash of Communities at the Seneca Women's Peace Encampment. Ithaca: Cornell University Press.

Lien, Carsten

1991. Olympic Battleground: The Power Politics of Timber Preservation. San Francisco: Sierra Club Books.

Lowood, Henry E.

1990. The Calculating Forester: Quantification, Cameral Science, and the Emergence of Scientific Forestry Management in Germany. In The Quantifying Spirit in the 18th 
Century. Tore Frangsmyr, J.L. Heilbron and Robin E. Rider, editors. Berkeley: University of California Press.

Lyotard, Jean-Francois

1984. The Postmodern Condition: A Report on Knowledge. Minneapolis: University of Minnesota Press.

Machlis, Gary E. and Jo E. Force

1988. Community Stability and Timber-Dependent Communities. Rural Sociology 53: 220-234.

Marino, Cesare

1990. History of Western Washington Since 1846. In The Handbook of North American Indians, Volume 7, Northwest Coast. Wayne Suttles, editor. Washington: Smithsonian.

Merchant, Carolyn

1989. The Death of Nature: Women, Ecology and the Scientific Revolution. New York: Harper Collins.

Miller, James D.

1988. Unexpected Walkouts in Pacific Northwest. Wall Street Journal. June 7:25.

Miller, Marc L.

1987. Tourism in Washington's Coastal Zone. Annals of Tourism Research 14: 58-70.

Myer, Richard E.

1992. Images of Logging on Contemporary Pacific Northwest Gravemarkers. In Cemeteries and Gravemarkers: Voices of American Culture. Richard E. Myer, editor. Logan: Utah State University Press.

Nathan, Holly

1993, Aboriginal Forestry: The Role of the First Nations. In Touch Wood: BC Forests at the Crossroads. Ken Drushka and Bob Nixon et al., editors. Madeira Park: Harbour Publishing.

Neel, David

1992. Our Chiefs and Elders: Words and Photographs of Native Leaders. Vancouver: University of British Columbia Press.

Parman, Donald L.

1983. Inconstant Advocacy: The Erosian of Indian Fishing Rights in the Pacific Northwest, 1933-

1956. Pacific Historical Review 53: 163-189.

Pavel, D. M. and G. B. Miller

1993. Too Long, Too Silent: The Threat to Cedar and the Sacred Ways of Skokomish. American Indian Culture and Research Journal 17(3):53-80.

Pearce, Adrian

1993. Environmental Protest, Bureaucratic Closure: The Politics of Discourse in Rural Ireland. In Environmentalism: The View from Anthropology. Milton Kay, editor. New York: Routledge.

Percival, Robert V., Alan S. Miller, Christopher H. Schroeder and James P. Leape 1996. Environmental Regulation: Law, Science and Policy. 2nd Edition. New York: Little, Brown and Company. 
Proctor, James D.

1995. Whose Nature? The Contested Moral Terrain of Ancient Forests. In Uncommon Ground: Rethinking the Human Place in Nature. William Cronon, editor. New York: W.W. Norton.

Prouty, Andrew Mason

1985. More Deadly than War! Pacific Coast Logging, 1827-1981. New York: Garland Publishing.

Ross, Andrew

1991. Strange Weather: Culture, Science and Technology in the Age of Limits. New York: Verso.

Scarce, Rik

1990. Eco-Warriors: Understanding the Radical Environmental Movement. Chicago: Noble Press.

Smith, Robert L.

1980. Ecology and Field Biology. 3rd edition. New York: Harper and Row.

Strathern, Marilyn

1992. After Nature: English Kinship in the Late Twentieth Century. New York: Cambridge University Press.

Soulé, Michael E. and Lease, Gary

1995. Reinventing nature?: Responses to Postmodern Deconstruction. Washington, D.C.: Island Press.

Swanson, Frederick J., Jerry F. Franklin and James R. Sedell

1989. Landscape Patterns, Disturbance, and Management in the Pacific Northwest, USA. In Changing Landscapes: An Ecological Perspective. Isaak S. Zonneveld and Richard T.T. Forman, editors. New York: Springer-Verlag.

Taylor, Walter and William L. Hanson

1970. Uncommon Controversy: Fishing Rights of the Muckleshoot, Puyallup, and Nisqually Indians. Seattle: University of Washington Press.

Time, Justin 1997. Ecosystem Mismanagement's Revolving Door. Earth First! Journal 17(3): 22.

Tollefson, Kenneth D.

1992a. Cultural Survival of the Snoqualmie Tribe. American Indian Culture and Research Journal 16(4): 29-53.

1992b The Political Survival of Landless Puget Sound Indians. American Indian Quarterly 16(2): 213-235.

Trumbull, Mark

1993. Small Northwest Businesses, Towns Hit Hard by Timber Compromise. Christian Science Monitor, 14 July: 6.

Tsing, Anna L.

1993. In the Realm of the Diamond Queen: Marginality in an Out-of-the-Way Place. Princeton: Princeton University Press.

Turner, Terence

1993.Anthropology and Multiculturalism: What is Anthropology that Multiculturalists Should Be Mindful of It? Cultural Anthropology 8: 411-429.

Turner, Victor

1974. Dramas, Fields, and Metaphors: Symbolic Action in Human Society. Ithaca:

Cornell University Press. 
Twight, Ben W.

1983. Organizational Values and Political Power: The Forest Service Versus the Olympic National Park. University Park: Pennsylvania State University Press.

Waldo, Jim

1988. Redefining Winning: The Timber/Fish/Wildlife Process. Forest Planning Canada 4(3): 14-19.

Walls, Robert E.

1987. Logger Poetry and the Expression of Worldview. Northwest Folklore 5(2): 1545.

1996. Green Commonwealth: Forestry, Labor, and Public Ritual in the Post-World War II Pacific Northwest. Pacific Northwest Quarterly 87(3): 117-129.

Warf, Barney

1988. Regional Transformation, Everyday Life, and Pacific Northwest Lumber Production. Annals of the Association of American Geographers 78(2): 326-346.

Warren, Kristin

1992. Role-Making and Coping Strategies among Women in Timber-Dependent Communities. M.S. thesis, University of Washington.

Webster, Peter S.

1978. As Far as I know: Reminiscences of an Ahousaht Elder. Campbell River, BC: Campbell River Museum.

White, Richard

1980. Land Use, Environment, and Social Change: The Shaping of Island County, Washington. Seattle: University of Washington Press.

1995. "Are You an Environmentalist or Do You Work for a Living?": Work and Nature. In Uncommon Ground: Rethinking the Human Place in Nature. William Cronon, (editor) New York: W.W. Norton.

Williams, C. Herb and Walt Neubrech 1976. Indian Treaties, American Nightmare. Seattle: Outdoor Empire Publishing.

Williams, Michael 1989. Americans and Their Forests: A Historical Geography. New York: Cambridge University Press.

Wilson, Alexander 1992. The Culture of Nature: North American Landscape from Disney to the Exxon Valdez. Cambridge: Blackwell.

Worster, Donald

1977. Nature's Economy: A History of Ecological Ideas. New York: Cambridge University Press.

\section{Abstract}

Land managers have recently shifted scientific practice and management discourse to depoliticize and suppress social conflicts over the environment. The transformation of the landscape of the Olympic Peninsula, particularly the logging of old-growth forests, has involved residents in challenging these developments, reordering the landscape to create contradictory, cultural claims to the future of the peninsula and its resources. 
Keywords: Forestry, natural resource management, science, environmentalism, Washington State.

\section{Résumé:}

Les gérants de terre ont changé récemment de pratique scientifique et le discours de gestion pour éliminer le discours politique et supprimer des conflits sociaux sur l'environnement. La transformation du paysage de la Péninsule Olympique, en particulier la coupe des forêts de croissance ancienne, a engagé des résidents en contestant ces développements, à refaire le paysage pour créer des revendications culturelles contradictoires à l'avenir de la péninsule et de ses ressources.

Les Mots-clefs La foresterie, la gestion des ressources naturelles, la science, environnementale, Washington State.

\section{Resumen}

Administradores de tierras han cambiado la práctica cientfica y su discurso de manejo en tiempos recientes para despolitizar y suprimir conflictos sobre el medio ambiente y la ecologa. La transformacin del paisaje de la Pennsula Olmpica, especialmente el corte de los bosques primarios ha provocado entre los residentes protestas contra este tipo de desarrollo, y usan sus reclamos culturales sobre los recursos de la pennsula para construir un paisaje reorganizado y distincto al actual.

Palabras claves: Silvicultura, manejo de recursos naturales, ciencia, medio ambiental, ecologa, Estado de Washington. 
Landscape and Politics on the Olympic Peninsula

\section{This Page Left Blank}

